\title{
Introduktion: Muslim og minoritet
}

af Lise Galal, Monique Hocke og Iram Khawaja

Forholdet mellem det 'at være muslim' og det 'at være en minoritet' har blandt muslimer været et emne til debat, siden profeten Muhammed udvandrede eller flygtede fra Mekka til Medina for dér at leve i eksil i 8 år. I dag kan man blandt andet på arabiske islamiske satellit-kanaler følge med i, hvordan denne debat er blevet en del af muslimers hverdagspraksis i Europa, hvor de forsøger at finde svar på, hvordan de skal leve som muslimer i samfund, hvor islam ikke er majoritetsreligionen.

At muslimer i Europa er en minoritet, er en commonsense betragtning, der florerer i den offentlige debat, i hverdagssproget, såvel som i forskningen på feltet. Ganske ofte tages denne betragtning af muslimers status for givet, uden at det udforskes nærmere, hvilke præmisser der ligger bag denne kategorisering, og hvad konsekvenserne er. For at komme nærmere en forståelse af sammenhængen mellem 'det at være muslim' og at være 'en minoritet', er det nødvendigt at udfordre denne commonsense forståelse af muslimer som værende en minoritet. Hvad menes der med, at de er en minoritet? Muslim er betegnelsen for en religiøs identitet, men hvad får det af betydning for det religiøse tilhørsforhold, den enkeltes hverdagslige tilværelse og selvforståelse, at muslimer betegnes som værende en minoritet? Er det overhovedet religionen, der er afgørende for deres minoritetsidentitet, og hvordan spiller den religiøse og den minoriserede kategorisering sammen? Set i forhold til majoritetens rolle må man blandt andet spørge, hvordan kategoriseringen af muslimer som værende en minoritet får betydning for lovgivning og institutionelle praksisser. Der er således rigtig mange aspekter af dette tema, som kunne være relevante at belyse.

Dette temanummer belyser nogle udvalgte aspekter af dette omfattende emne om den religiøse $o g$ minoriserede identitet. Disse aspekter afspejler til dels den forskning, der aktuelt dominerer i det danske forskningsfelt, og er til dels influeret af politiske interesser for integration, antiradikalisering, muslimsk identitet etc. Ambitionen er en tværfaglig vinkling på konstruktioner af muslimske minoritetsidentiteter med en særlig opmærksomhed på samspillet mellem den religiøst definerede og den status- eller magt-definerede identitet, som minoritetsbegrebet refererer til. Temanummeret tager således udgangspunkt i en definition af minoriteter som en analytisk kategori, hvor minoriteten er defineret ved en asymmetrisk magtrelation til majoriteten. Det er dermed ikke det numeriske mindretal, der i sig selv gør muslimer til en minoritet, men tilskrivningen af 
betydning til gruppen af muslimer og dens størrelse i relationen til en majoritet. Denne magtrelationelle - betydningstilskrivning tildeler minoriteten en anderledes, afvigende eller negativ identitet, der fratager minoriteten samfundsmæssig status og definitionsmagt. Hvilke forskelle i form af afvigelser fra normen, der konkret tillægges betydning, kan samtidig variere over tid og sted og være udgangspunkt for forhandlinger og kampe, som det tydeligt vil fremgå af dette temanummers artikler. Alle artikler i dette temanummer synes - eksplicit eller implicit - at tage udgangspunkt i denne definition af minoriteten. Daniel Henchen viser, hvordan danske missionærer i Syrien i begyndelsen af det 20. århundrede ikke blot definerer muslimer som objekter for mission, men definerer beduiner som særligt missionsmodtagelige. Definitionen af minoriteten blandt minoriteten - nemlig beduinen - bliver dermed en definition med et praktisk formål: mission, og dét er udgangspunktet for, hvordan beduinen og de andre muslimer betydningstillægges i relation til islam såvel som kristendom. Pointen, om at definitionen af minoriteten har et praktisk formål, er gennemgående for flere af artiklerne. Lasse Lindekilde spørger således til sammenhængen mellem særlige integrations- og antiradikaliseringsindsatser og radikalisering blandt muslimer. Integrationsindsatsen er formuleret på baggrund af udgrænsningen af en særlig gruppe, en minoritet i samfundet, der tilskrives et særligt behov for hjælp til at blive integreret. Spørgsmålet, som Lindekilde også rejser, er, om det er selve indsatsen, minoriteten reagerer på, eller kategoriseringen, idet denne netop af mange opleves og opfattes som en eksklusion snarere end et oprigtigt forsøg på inklusion. Minoritetsdefinitionen er altså ikke ligegyldig eller blot et spørgsmål om akademisk spilfægteri, men har direkte konsekvenser for social praksis, og er derfor også væsentlig at udforske som netop social praksis.

I forlængelse af udpegningen af den 'praktiske' minoritet, som eksempelvis enten skal omvendes eller integreres, rejser der sig et andet spørgsmål knyttet til temaet for dette nummer. Hvordan er islam - eller dét at være muslim - blevet det aspekt, der betydningstilskrives som anderledes, afvigende eller negativt, og hvordan finder det sted og opleves af de involverede parter? I denne forbindelse er det centralt at være opmærksom på, hvordan den muslimske identitet som forklaringsmodel konvergerer med andre faktorer, så som etnicitet, migrantstatus, køn, klasse etc. De fleste er opmærksomme på, at den dominerende 'praktiske' minoritet de seneste 10-15 år i den danske politiske debat i stigende grad synes at være blevet muslimer, hvor det tidligere var flygtninge og længere igen tilbage, migrantarbejdere. Der er gode grunde til at hævde, at intersektionen af immigrant (og efterkommere heraf) og muslim derfor ikke kan adskilles. Den 
muslimske minoritet er stadig betydningsindskrevet $\mathrm{i}$ en integrationsdiskurs, der strukturerer rammerne for, hvordan den muslimske identitet tilskrives betydning. At det nu er religionen, snarere end tidligere kulturen eller klassetilhørsforholdet, der bliver tillagt betydning, ikke blot illustrerer, hvordan tilskrivningen af betydning ændres over tid og sted, men er vigtig for forståelsen af minoritetens strategier og handlemuligheder. Hvordan islam og kategorien muslim bliver til og forhandles er noget, som særligt Tekla Canger kommer ind på i sin artikel. På baggrund af livshistoriske interviews af minoriserede kvinder med muslimsk baggrund analyseres positioneringen 'muslim' som en grundlæggende intersektionel og sammenvævet konstruktion, der på forskellig vis konvergerer med andre sociale kategorier og kontekstuelle positioneringer. Canger kommer blandt andet ind på de unges muligheder for at skabe et "tredje rum" i deres forhandlinger af en muslimsk andethed.

At skabe en 'praktisk' minoritet indebærer for det tredje, at den tillægges betydning som anderledes, hvilket sker gennem specifikke kategoriseringer og repræsentationer. Det sker i mange forskelligartede kontekster, som herværende artikler hver især eksemplificerer. Gennem sammenligninger af fremstillinger af jøden i begyndelsen af det 20. århundrede med fremstillinger af muslimen i begyndelsen af det 21. århundrede, argumenterer Cora Alexa Døving således for, at selve konstruktionen af 'minoritetsstereotypen' synes at have fællestræk på tværs af tid og rum. Fremstillingerne, der analyseres, er fra den norske offentlige debat i form af avisartikler, bøger, pamfletter mv. Signe Kjær Jørgensen undersøger muslimers betingelser for selvfremstilling i medierne gennem en analyse af et interview med Asmaa Abdol-Hamid i Politiken. Her argumenterer Kjær Jørgensen for, at minoriteten har stærkt afgrænsede muligheder for selvfremstilling, idet betingelserne herfor udstikkes af majoritetens normativitet og forforståelser. Medierne er således én kontekst for kategorisering og repræsentation. I Lindekildes artikel vises, hvordan det politiske tiltag om brugen af rollemodeller som integrationsfremmende og radikaliseringshæmmende redskab implicit opererer med kategoriseringer. Den institutionaliserede politiske praksis er således en anden kontekst for kategorisering. Den politiske diskurs om muslimer og særligt radikaliserede muslimer er ligeledes central i Iben Helqvists artikel, da embedsmandsværket indretter deres politiske praksis i forbindelse med valg af muslimske samtalepartnere efter politikeres og mediers offentlige kategoriseringer af specifikke muslimer og muslimske organisationer som værende radikale eller ekstreme i deres islamfortolkning. Her konvergerer de mediebårne kategoriseringer med institutionaliseret politisk praksis. Imidlertid viser 
Helqvists artikel, at minoritetens vilje til tilhørsforhold og krav om anerkendelse som ligeværdige borgere i det danske samfund blandt andet artikuleres gennem netop den demokratiske proces. Således peger Helqvist på muslimske organisationers forhandling af at repræsentere en dansk islam og indgå som samarbejdspartnere i en national politisk kontekst.

Som det fremgår af dette bud på minoritetsperspektiver, som dette temanummers artikler kan læses med, handler temaet muslim og minoritet ikke så meget om islam, som det handler om muslimsk identitet i en særlig form for samfundsmæssighed. Adskillige af de boganmeldelser, som også rummes i dette nummer, har samme interessefelt. Det er med interesse for dette felt, at vi opfordrer læserne til at læse dette nummer af Tidsskrift for Islamforskning. 